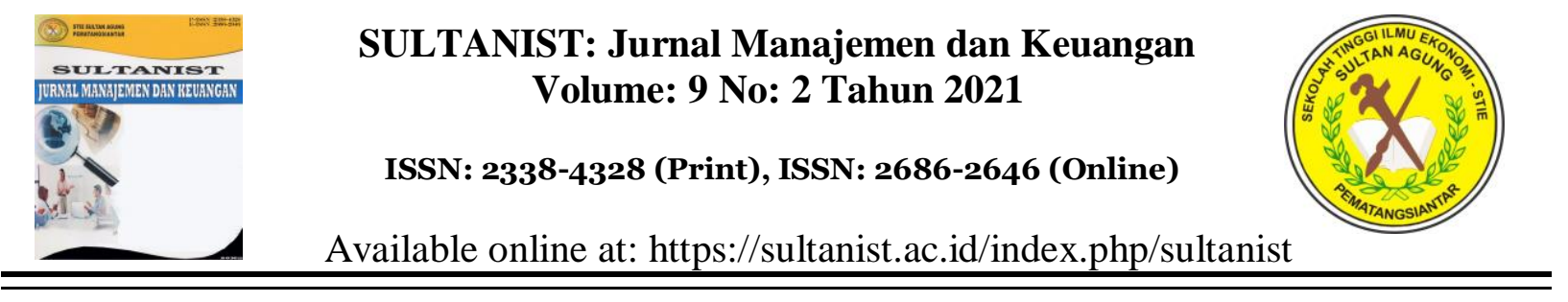

\title{
ANALISIS KANONIK KARAKTERISTIK KONSUMEN KUALITAS PELAYANAN DAN KEPUASAN KONSUMEN PEMBELIAN KEMBALI PADA MARKET PLACE TOKOPEDIA
}

\author{
Harkim $^{1 *)}$, Christ Holy S. ${ }^{2)}$, Audina Simanungkalit ${ }^{3)}$, Denny Martin Tambunan, Sofiyan \\ ${ }^{123}$ Program Studi Manajemen, STIE Profesional Indonesia \\ ${ }^{4}$ Program Studi Magister Ilmu Manajemen, Sekolah Tinggi Ilmu Ekonomi Sultan Agung
}

*E-mail: ${ }^{1}$ harkimsimamora@gmail.com, ${ }^{2}$ christholi40@gmail.com, ${ }^{3}$ dennymartin356@ gmail.com

\begin{abstract}
Abstrak
Perubahan besar yang disebabkan pesatnya perkembangan teknologi informasi dan telekomnukasi telah merubah prilaku dan gaya hidup masyarakat luas dalam segala sendi-sendi kehidupan mereka. Internet menjelma menjadi media baru bagi pemasaran produk dan jasa, dan tempat transaksi jual beli secara digital dalam wadah yang bersifat virtual (maya). Tujuan dalam penelitian ini adalah melakukan analisis korelasi kanonik hubungan karakteristik konsumen dan kualitas pelayanan pada market place Tokopedia dengan kepuasan pelanggan dan keputusan pembelian kembali yang dilakukan pelanggan pada market place tokopedi. Teknik analisis data dengan menggunakan analisis korelasi kanonik untuk menggambarkan hubungan antara variabel independen dengan variabel dependen secara bersamaan. Analisis korelasi kanonik merupakan teknik statistika multivariat yang dikembangkan oleh Hoteling (1936), metode ini dikembangkan untuk mengidentifikasi dan mengukur tingkat keratan hubungan linier antara dua himpunan variabel, himpunan variabel dependen dan himpunan variabel independen yang diukur pada unit sampling yang sama. Variabel independen yang mempunyai hubungan paling kuat yakni yang memiliki dengan nilai muatan kanonik terbesar dengan kepuasan konsumen dan keputusan pembelian kembali adalah variabel kualitas pelayanan. Sedangkan Variabel yang memiliki kontribusi terbesar dalam kelompok variabel dependen adalah variabel kepuaasan pelanggan dengan bobot kanonik terbesar. Sedangkan Variabel yang memiliki kontribusi paling besar dalam kelompok variabel independen adalah variabel kualitas pelayanan dengan bobot kanonik terbesar.
\end{abstract}

Kata kunci: karakteristik konsumen, kualitas pelayanan, kepuasan konsumen, pembelian kembali

\section{CANONIC ANALYSIS OF CUSTOMER CHARACTERISTICS SERVICE QUALITY AND CUSTOMER SATISFACTION PURCHASE BACK AT TOKOPEDIA MARKET PLACE}

\begin{abstract}
Major changes caused by the rapid development of information technology and telecommunications have changed the behavior and lifestyle of the wider community in all aspects of their lives. The internet has become a new medium for marketing products and services, and a place for buying and selling digitally in a virtual (virtual) container. The purpose of this study is to analyze the canonical correlation of the relationship between consumer characteristics and service quality at the Tokopedia market place with customer satisfaction and repurchase decisions made by customers at the Tokopedia market place. The data analysis technique uses canonical correlation analysis to describe the relationship between the independent variable and the dependent variable simultaneously. Canonical correlation analysis is a multivariate statistical technique developed by Hoteling (1936), this method was developed to identify and measure the level of linear relationship between two sets of variables, the set of dependent variables and the set of independent variables measured in the same sampling unit. The independent variable that has the strongest relationship is the one with the largest canonical content value with consumer satisfaction and repurchase decisions is the service quality variable. While the variable that has the largest contribution in the dependent variable group is the customer satisfaction variable with the largest canonical weight. While the variable that has the largest contribution in the group of independent variables is the service quality variable with the largest canonical weight.
\end{abstract}

Keywords: consumer characteristics, service quality, customer satisfaction, repurchase

Article History: Received: 30 Oktober 2021 Revised: 22 November 2021 Accepted: 22 November 2021 


\section{PENDAHULUAN}

Perubahan besar yang disebabkan pesatnya perkembangan teknologi informasi dan telekomnukasi telah merubah prilaku dan gaya hidup masyarakat luas dalam segala sendi-sendi kehidupan mereka. Tidak bisa dipungkiri, perubahan dalam gaya kehidupan sehari-hari manusia banyak dipengaruhi oleh aplikasi dari produkproduk teknologi informasi. Internet sebagai salah satu media baru yang merupakan produk dari teknologi informasi dan komunikasi tersebut telah banyak membawa perubahan besar terutama kepada kegiatankegiatan bisnis dan ekonomi di tengah masyarakat (Rumondang et al., 2020).

Internet menjelma menjadi media baru bagi pemasaran produk dan jasa, dan tempat transaksi jual beli secara digital dalam wadah yang bersifat virtual (maya). Sehingga jika dahulu konsumen harus mengunjungi pusat-pusat perbelanjaan atau toko secara langsung untuk membeli sebuah produk atau jasa, saat ini hal tersebut dapat dilakukan kapan saja dan dimana saja dengan mudah menggunakan gadget atau perangkat komunikasi lain yang terhubung melalui internet (Sudirman, Efendi, et al., 2020).

Salah satu karakteristik penting pengguna internet berdasarkan data yang dirilis oleh Asosiasi Penyelenggara Jasa Internet Indonesia (APJII) pada tahun 2018 adalah bahwa dapat disimpulkan bahwa pengguna internet dari segi umur didominasi oleh kelompok dari kelompok umur 15-19 dengan penetrasi paling tinggi mencapai 91 persen, selanjutnya kelompok umur 20-24 tahun dengan penetrasi sebesar 88,5 persen, dan selanjutnya ada kelompok umur 25-29 tahun dengan penetrasi 82,7 persen, kelompok umur 30-34 tahun dengan penetrasi 76,5 persen, dan 76,5 persen, dan kelompok umur 35-39 tahun dengan penetrasi 68,5 persen.

Pesatnya penggunaan internet saat ini juga menyebabkan munculnya situs-situs market place yakni bentuk perusahaan ecommerce di Indonesia banyak yang menerapkan sistem customer to customer (C2C) atau yang lebih dikenal dengan sebutan marketplace. Marketplace akan berperan sebagai fasilitator dalam belanja online dimana contoh marketplace yang ada di Indonesia antara lain Shopee, Bukalapak, Tokopedia, Lazada dan lain sebagainya.

Tabel 1. Jumlah Kunjungan Pengguna Intenet Pada Market Place Periode Kuartal I

\begin{tabular}{|l|l|}
\multicolumn{2}{c}{2019} \\
\hline Marketplace & Jumlah Kunjungan \\
\hline Tokopedia & $137,200,900$ \\
\hline Bukalapak & $115,256,600$ \\
\hline Shopee & $74,995,300$ \\
\hline Lazada & $52,044,500$ \\
\hline Blibli & $32,597,200$ \\
\hline
\end{tabular}

Sumber: https://iprice.co.id//insights data

Salah satu marketplace yang sangat pesat pertumbuhannya di Indonesia adalah Tokopedia yang merupakan marketplace dengan kunjungan tertinggi selama periode tahun 2019. Dari data pada tabel berikut ditunjukkan bahwa jumlah pengunjung pada kuartal I tahun 2019 didominasi oleh Tokopedia dengan total kunjungan 137,200,900, disusul dengan para pesaingnya seperti Bukalapak total kunjungan 115,256,600, Shopee total kunjungan 74,995,300 Lazada total kunjungan 52,044,500, dan Blibli total kunjungan 32,597,200. Persaingan diantara market place saat ini sangat ketat, untuk memenangkan pangsa pasar yang semakin sempit. Pihak pembeli saat ini sangat kritis terhadap pelayanan yang diberikan oleh tiap-tiap market place. Beberapa indikator yang saat ini menentukan apakah yang dharapkan oleh penggunanya adalah ditunjukkan oleh Tabel berikut: 
Tabel 2. Faktor-Faktor Yang Menentukan Seseorang Menggunakan Sebuah Market Place

\begin{tabular}{|l|l|}
\hline 1 & Good Reputation \\
\hline 2 & Cheaper Product Price \\
\hline 3 & More Produk Selection \\
\hline 4 & Authentic Products \\
\hline 5 & Good Customer Service \\
\hline 6 & Fast Delivery \\
\hline 7 & Free Delivery \\
\hline 8 & Easy Return Policy \\
\hline 9 & Easy Navigation on Site \\
\hline 10 & Loyalty Program \\
\hline 11 & Better Mobile App \\
\hline
\end{tabular}

Sumber : https://ecommerceiq.asia/

Indikator-indikator

tersebut sebenarnya merupakan usaha yang terbentuk atau dilakukan pengelola market place untuk mempertahankan para konsumennya dengan terus meningkatkan mutu pelayanannya. Mengingat konsumen merupakan salah satu aset penting dan menentukan maju mundurnya perusahaan. Faktor reputasi dan harga menunjukkan bahwa konsumen dalam menggunakan sebuah market place akan memperhatikan reputasi yang diberikan konsumen lain terhadap market place tersebut. Jadi jika seorang puas dan memberikan reputas umumnya berbentuk ulasan, maka ulasan ini akan dapat dibaca secara luas oleh konsumen lain sebelum melakukan transaksai di market place tersebut.

Ulasan yang baik tentu berasal dari rasa puasa atas pelayanan yang diberikan market place tersebut. Oleh karena itu indikator penting yang dapat digunakan untuk mengukur kepuasan konsumen adalah kualitas pelayanan. Dengan adanya pelayanan yang baik akan membuat konsumen dapat memperoleh nilai atas apa yang mereka korbankan untuk mendapatkan sesuatu sesuai dengan yang mereka harapkan. Slywotzky (1996) menyatakan bahwa menciptakan dan memberikan nilai pelanggan superior kepada high-value consumers bisa meningkatkan nilai sebuah organisasi. Menurut Tjiptono (2011), model kualitas layanan yang paling populer dan hingga kini banyak dijadikan acuan dalam penilaian kualitas jasa adalah model Servqual (singkatan dari service quality). Pengukuran kualitas pelayanan pada model ini didasarkan atas pelayanan yang diharapkan pelanggan (expected service) dan persepsi terhadap pelayanan (perceived service) pada lima dimensi kualitas pelayanan, yaitu dimensi reliabilitas, daya tanggap, jaminan, empati, dan bukti fisik.

Pemahaman yang baik tentang kepuasan pelanggan merupakan salah satu hal penting yang dapat membantu dalam menentukan kebijakan dan pengambilan keputusan untuk upaya perbaikan mutu pelayanan sebuah market place (Sudirman, Sherly, et al., 2020). Dengan mengetahui kepuasan pengguna terhadap pelayanan market place yang diterimanya, evaluasi dan proyeksi dalam penentuan kebijakan dimasa depan akan lebih mudah untuk dilakukan. Jika pelanggan merasa puas untuk selanjutnya dia akan memperlihatkan peluang untuk melakukan pembelian ulang yang jauh lebih tinggi dalam kesempatan berikutnya dibandingkan pelanggan yang kurang puas. Kepuasan dan pembelian ulang merupakan salah satu perilaku yang sekuensi karena pembelian yang sebelumnya menghasilkan kepuasan dan menjadi dasar keputusan pembelian berikutnya.

Hubungan antara kualitas layanan, kepuasan pelanggan, dan pembelian kembali mungkin sudah banyak di analisis dalam penelitian-penelitian manajemen pemasaran. Penelitian kali ini melanjutkan penelitianpenelitian terdahulu dengan menggunakan analisis korelasi kanonik, sebuah teknik analisis statistik multivariat yang berfokus pada korelasi antara kombinasi linier satu set variabel dengan kombinasi linier set variabel yang lain (Suzanna, 2013). Berdasarkan latar belakang yang telah dipaparkan, rumusan masalah dalam penelitian ini adalah Analisis Korelasi 
Kanonik Hubungan Karakteristik Pengguna Market Place Tokopedia dan Kualitas Pelayanan Tokopedia dengan Kepuasan Pelanggan dan Keputusan Pembelian Kembali yang dilakukan pelanggan pada Market Place Tokopedia.

\section{LANDASAN TEORI}

\section{Karakteristik Pelanggan}

Berbicara mengenai karakteristik pelanggan tidak akan lepasa dari konsep segmentasi pelanggan. Sebuah strategi untuk menarik lebih banyak pelanggan dengan cara mengelompokkan mereka dalam beberapa kelompok yang berbeda. Segmentasi pasar menurut Kotler (2012) pasar yang terdiri dari sekelompok pelanggan yang memiliki sekumpulan kebutuhan dan keinginan yang serupa. Menurut Kasali (1998), segmentasi adalah proses mengkotak-kotakan pasar (yang heterogen) ke dalam kelompok-kelompok "potential costumers" yang memiliki kesamaan kebutuhan dan/atau kesamaan karakter yang memiliki respon yang sama dalam membelanjakan uangnya. Karena sifatnya yang homogen, maka akan sulit bagi produsen untuk melayaninya, oleh karena itu pemasar harus memilih segmensegmen tertentu saja dan meninggalkan bagian pasar lainnya.

Kelompok-kelompok nantinya dikumpulkan berdasar sifat-sifat pelanggan, misalnya kebutuhan dan perilaku konsumsi mereka. Di samping itu, segmentasi pelanggan juga dapat dilakukan dengan mengelompokkan mereka sesuai demografi (usia, jenis kelamin, hingga profesi). Pengelompokan ini kemudian dilanjutkan dengan menentukan proposisi nilai. Setiap kelompok diberikan proposisi nilai yang paling sesuai dengan karakteristiknya masing-masing. Setelah itu kemudian barulah Anda menerapkan model bisnis yang mampu memenuhi kebutuhan dari segmen-segmen tersebut. Suatu organisasi dapat mengkategorikan konsumen ke dalam kelompok yang berbeda jika memiliki karakteristik berikut.

\section{Pengertian dan Pentingnya Memahami Perilaku Konsumen}

Agar memperoleh gambaran yang jelas tentang perilaku konsumen, berikut akan dikemukakan definisi perilaku konsumen menurut beberapa penulis. Hawkins (1998) mengemukakan bahwa perilaku konsumen (consumer behavior) adalah studi terhadap individu, kelompok atau organisasi dan proses yang mereka gunakan untuk memilih, mengamankan, menggunakan dan menentukan produk, service, pengalaman atau ide untuk memuaskan kebutuhan dan dampak proses tersebut pada konsumen atau masyarakat. Engel (1995) menyatakan bahwa perilaku konsumen adalah tindakan yang langsung terlibat untuk mendapatkan, mengkonsumsi dan menghabiskan produk dan jasa, termasuk proses yang mendahului dan mengikuti tindakan ini. Dari berbagai definisi tersebut dapat ditarik beberapa kesimpulan bahwa:

1. Perilaku konsumen menyoroti perilaku baik individu maupun rumah tangga.

2. Inti dari perilaku konsumen adalah proses pengambilan keputusan pembelian barang atau jasa

3. Tujuan mempelajari perilaku konsumen adalah untuk menyusun strategi pemasaran yang berhasil.

Para pemasar wajib memahami keragaman perilaku konsumen agar mampu memasarkan produknya dengan baik. Di samping itu, para pemasar juga perlu memahami mengapa dan bagaimana konsumen mengambil keputusan membeli, sehingga pemasar dapat merancang strategi pemasar.

\section{Dampak Memahami Kaakteristik Bagi Pelanggan}

Apa dampak terhadap pelanggan dari memahami karakteristik mereka? Dengan 
memahami pelanggan, maka perusahaan dapat memahami bahwa pelanggan pun memiliki karakteristik khusus saat berinteraksi dengan produk. Hal ini akan memudahkan pntuk menyusun strategi bisnis selanjutnya. Perusahaan bisa dengan mudah menentukan mana produk yang sebaiknya ditingkatkan produksinya dan mana yang sebaiknya ditarik. Hingga saat ini, segmentasi pelanggan masih menjadi strategi bisnis yang relevan. Ini karena pelanggan memang memiliki karakteristik yang sangat bervariasi. Anda pun bisa menerapkan starategi ini saat membangun usaha sendiri. Dengan menerapkan segmentasi pelanggan, Anda bukan hanya bisa mendapat pelanggan baru, tetapi juga pelanggan yang loyal pada produk Anda.

\section{Kualitas Pelayanan}

Menurut Tjiptono (2007) yang mendefinisikan kualitas pelayanan sebagai suatu upaya yang dilakukan untuk memenuhi kebutuhan dan keinginan konsumen dengan penyampaian yang tepat dan juga berimbang. Menurut Kotler dan Keller (2009: 65) mendefinisikan kualitas pelayanan adalah setiap tindakan atau kegiatan yang dapat ditawarkan oleh suatu pihak kepada pihak lain, yang pada dasarnya tidak berwujud dan tidak menghasilkan kepemilikan apapun. Menurut Ratnasari dan Aksa, (2011:104) Kualitas pelayanan secara sederhana merupakan ukuran seberapa bagus tingkat layanan yang diberikan mampu terwujud sesuai dengan ekspektasi pelanggan, dengan kata lain kualitas pelayanan adalah sejauh mana pelayanan memenuhi spesifikasinya.

Berdasarkan penjelasan diatas dapat disimpulkan bahwa kualitas pelayanan adalah segala bentuk upaya yang ditawarkan oleh perusahaan yang dapat memenuhi kebutuhan dan keinginan pelanggan sehingga pelanggan dapat merasa puas. Menurut Ratnasari dan Aksa (2011) terdapat lima indikator pokok pada kualitas pelayanan yaitu sebagai berikut:
1. Tangibles (bukti langsung)

2. Reliability (kehandalan)

3. Responsiveness (daya tanggap)

4. Assurance (jaminan)

5. Empathy (empati)

Tangiable (bukti langsung) adalah kemampuan perusahaan untuk menunjukkan eksistensi atau keberadaannya kepada masyarakat umum dengan bukti - bukti fisik yang dimilikinya, baik itu berupa aset bergerak maupun tidak bergerak. Realibility (kehandalan) merupakan bentuk profesionalisme dan atau kehandalan perusahaan dalam memberikan pelayanan secara akurat dan terpercaya sesuai dengan apa yang dibutuhkan oleh para pelanggannya. Responsivness (Daya Tanggap) adalah bentuk ketanggapan yang harus dimiliki oleh semua perusahaan penyedia jasa dalam membantu dan juga memberikan pelayanan kepada pelanggan, dengan penyampaian informasi yang jelas dan juga tepat. Assurance (jaminan) adalah cara atau kemampuan yang digunakan oleh perusahaan penyedia jasa layanan untuk meyakinkan para pelanggan kepada perusahaan jasa terkait yang salah satu caranya dilakukan dengan cara membangun komunikasi yang baik antara perusahaan dan pelanggan. Emphaty (empati) adalah suatu bentuk kepedulian yang diberikan oleh perusahaan penyedia jasa saat memberikan pelayanan terhadap pelanggannya, sehingga perusahaan penyedia jasa dapat dapat memenuhi sesuatu yang menjadi kebutuhan pelanggan tersebut secara lebih spesifik.

\section{Kepuasan Pelanggan}

Kepuasan pelanggan telah menjadi bagian dari perusahaan dalam rangka mencapai tujuan maupun dalam mewujudkan misinya. Kepuasan pelanggan merupakan perasaan senang atau kecewa dari suatu individu yang muncul akibat terpenuhinya ekspektasi pelanggan terhadap suatu objek seperti kualitas pelayanan dan produk. Menurut Oliver dalam Indriyani 
dam Helling (2018) kepuasan adalah tingkat perasaan seseorang setelah membandingkan kinerja/hasil yang dirasakan dengan harapannya. Menurut Kotler dan Keller (2009: 138) Kepuasan pelanggan adalah perasaan senang atau kecewa seseorang yang muncul setelah membandingkan antara harapan terhadap kenyataan yang diperoleh. Jadi kepuasan merupakan fungsi dari persepsi atau kesan atas kinerja dan harapan. Jika kinerja berada dibawah harapan maka pelanggan tidak puas.

Sebaliknya jika kinerja memenuhi harapan maka pelanggan akan puas. Jika kinerja melebihi harapan maka pelanggan akan sangat puas atau senang. Dari pernyataan di atas dapat disimpulkan bahwa memuaskan kebutuhan konsumen adalah keinginan setiap perusahaan. Selain factor penting bagi keberlangsungan hidup perusahaan, memuaskan kebutuhan konsumen dapat meningkatkan keunggulan dalam persaingan. Jika konsumen telah merasa terpuaskan, maka akan terciptalah sebuah hubungan kerjasama yang baik antara konsumen dengan perusahaan.

\section{Faktor-Faktor Yang Mempengruhi Kepuasan Pelanggan}

Menurut Irawan (2008:37-40) terdapat 5 faktor yang mempengaruhi kepuasan konsumen yaitu sebagai berikut: Kualitas produk adalah driver kepuasan konsumen yang multi dimensi. Konsumen akan puas dengan produk yang dibeli jika produk tersebut berkualitas baik. Harga, konsumen yang sensitif terhadap harga murah adalah sumber kepuasan yang penting karena mereka mendapatkan nilai yang tinggi. Service quality adalah konsep pelayanan yang terdiri dari tangibles, responsiveness, reliability, assurace, dan empathy. Emosional faktor adalah faktor yang berhubungan dengan gaya hidup seseorang. Biaya dan kemudahan adalah konsumen akan semakin puas dengan relatif mudah, nyaman dan efisien dalam mendapatkan produk dan pelayanan. Menurut Suwardi
(2011) dalam Cahyani dan Sitohang (2016) menyatakan bahwa kunci untuk mempertahankan konsumen adalah kepuasan konsumen. Adapun indikator kepuasan pelanggan yaitu Elitan (1999) :

1. Tidak menimbulkan keluhan.

2. Perasaan senang pada keseluruhan produk/jasa.

3. Kesesuaian pelayanan dengan ekspektasi.

4. Harapan pelanggan yang terlampaui.

\section{Pembelian Kembali}

Terjadinya pembelian ulang tergantung pada tingkat kepuasan pelanggan. Menurut Hellier dkk (2003) menuturkan Repurchase Intention atau minat beli ulang adalah keputusan terencana seseorang untuk melakukan pembelian kembali atas produk dan jasa tertentu, dengan mempertimbangkan situasi pengalaman yang terjadi setelah berbelanja melalui respon positif atau negatif. Menurut Swastha dan Handoko (2016) Minat beli ulang adalah keinginan untuk melakukan pembelian ulang dari yang pernah dilakukan oleh pembeli terhadap suatu produk atau jasa yang sama.

Sedangkan menurut Kotler (2005:255) dalam proses pembelian, niat beli atau niat pembelian ulang konsumen ini berkaitan erat dengan motif yang dimilikinya untuk memakai ataupun membeli produk tertentu. Motif pembelian ini berbeda-beda untuk setiap konsumen. Konsumen akan memilih produk yang mengandung atribut. Berdasarkan hasil penelitian yang telah dilakukan oleh Putri (2016) ada 6 faktor yang mempengaruh pembelian kembali konsumen yaitu:

1. Kepuasan Konsumen

2. Kualitas Layanan.

3. Preferensi Merek

4. Kualitas Produk

5. Nilai yang Dirasakan

6. Harga

Menurut Ferdinand

menjelaskan bahwa terdapat 4 indikator 
yang dapat mengukur pembelian kembali yaitu: $\quad$ Minat Transaksional, Menggambarkan perilaku seseorang yang berkeinginan untuk selalu membeli ulang produk yang telah dikonsumsi. Minat Referensial, menggambarkan perilaku seseorang untuk mereferensikan produk yang sudah dibeli supaya dikonsumsi juga oleh orang lain. Minat Preferensial, menggambarkan perilaku seseorang yang selalu memiliki preferensi utama pada produk yang telah dikonkumsinya. Preferensi ini dapat diganti bila terjadi sesuatu dengan produk preferensinya. Minat Ekploratif, menggambarkan perilaku seseorang yang selalu mencari informasi mengenai produk yang diminatinya dan mencari informasi untuk mendukung sifatsifat positif dari produk yang digemarinya tersebut.

\section{Kerangka Penelitian}

Adapun kerangka dalam penelitian ini dapat dilihat pada gambar berikut:

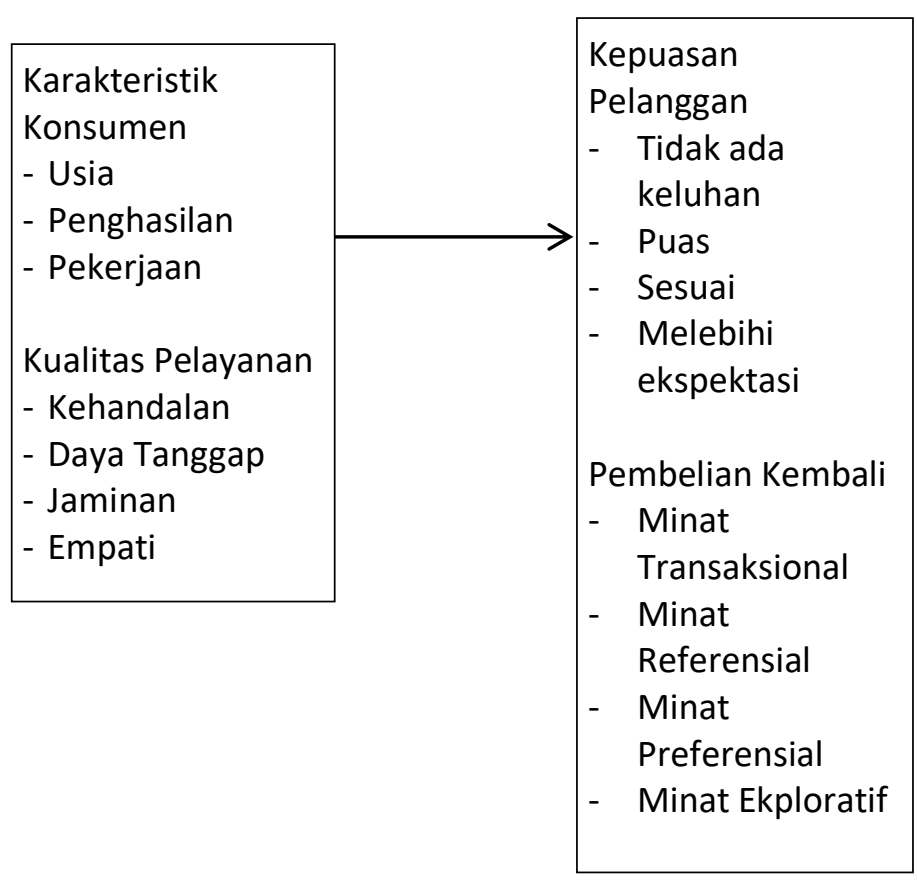

Gambar 1. Kerangka Pemikiran

Ada hubungan secara bersama-sama antara karakteristik konsumen dan kualitas pelayanan dengan kepuasan pelanggan dan tindakan pembelian kembali pada konsumen di market place Tokopedia.

\section{METODE}

Metode penelitian yang digunakan pada penilitian ini adalah explanatory research, yaitu penelitian yang digunakan untuk menjelaskan hubungan dan pengaruh antara variabel dependen dan variabel independen, melalui pengkajian hipotesis yang telah dirumuskan. Menurut Sugiyon (2013), metode explanatory research merupakan metode penelitian yang bermaksud menjelaskan kedudukan variabel-variabel yang diteliti serta pengaruh antara satu variabel dengan variabel yang lain. Populasi adalah wilayah generalisasi yang terdiri atas objek atau subjek yang mempunyai kualitas atau karakteristik tertentu yang ditetapkan oleh peneliti untuk dipelajari kemudian dan ditarik kesimpulannya (Sugiyono, 2015).

Menurut Sugiyono (2015), sampel adalah bagian dari jumlah dan karakteristik yang dimiliki oleh populasi. Tehnik pengambilan sampel dalam penelitian ini yaitu menggunakan teknik non probability sampling yaitu setiap elemen dalam populasi tidak memiliki kesempatan yang sama untuk dipilih menjadi sampel. Secara spesifik tehnik non probability sampling yang digunakan adalah purposive sampling atau judgement sampling yaitu metode penarikan sampel dengan pertimbangan tertentu berdasarkan kriteria yang ditetapkan dalam penelitian. Untuk menentukan berapa jumlah sampel yang tidak diketahui maka Menurut Sugiyono (2017), rumus dalam menghitung sampel pada populasi yang tidak diketahui adalah sebagai berikut:

Keterangan :

$$
\mathrm{n}=\frac{\mathrm{Z}^{2} \mathrm{pq}}{\mathrm{e}^{2}}
$$

$\mathrm{n} \quad=$ Jumlah sampel

$\mathrm{Z}^{2}=$ Harga dalam kurve nomal untuk simpanan 5\%, dengan nilai $=1,96$

$\mathrm{p} \quad=$ Peluang benar $50 \%=0,5$ 


$$
\begin{array}{ll}
\mathrm{q} & =\text { Peluang salah } 50 \%=0,5 \\
\mathrm{e} \quad=\text { Tingkat kesalahan sampel } & \\
\mathrm{n} & =\frac{(1,96)^{2}(0,5)(0,5)}{(0,1)^{2}} \\
\mathrm{n} & =\frac{0,9604}{0,01} \\
\mathrm{n} & =96,04=96
\end{array}
$$

Dari hasil rumus di atas maka dapat ditunjukan bahwa jumlah sampel dalam penelitian ini yaitu sebanyak 96 orang sampel, dengan ketentuan sampel tersebut adalah mereka yang pernah berbelanja minimal dua kali pada marketplace tokopedia.

Teknik analisis data dengan menggunakan analisis korelasi kanonik untuk menggambarkan hubungan antara variabel independen dengan variabel dependen secara bersamaan. Analisis korelasi kanonik merupakan teknik statistika multivariat yang dikembangkan oleh Hoteling (1936), metode ini dikembangkan untuk mengidentifikasi dan mengukur tingkat keratan hubungan linier antara dua himpunan variabel, himpunan variabel dependen dan himpunan variabel independen yang diukur pada unit sampling yang sama. Korelasi kanonik berfokus pada korelasi maksimum antara kombinasi linear himpunan variabel dependen dengan kombinasi linear himpunan variabel independen.

Uji normalitas pada analisis korelasi kanonik dilakukan dengan menguji normalitas terhadap setiap variabel. Pengujian normalitas dilakukan dengan uji Kolmogorov-Smirnov. Dengan pengujian normalitas terhadap setiap variabel diasumsikan bahwa variabel-variabelnya telah normal secara bersama-sama. Uji Multikolinearitas bertujuan untuk menguji apakah pada model yang terbentuk ditemukan adanya korelasi antar variabel bebas. Pengujian multikolinearitas dapat dilakukan dengan dua cara, yaitu dengan melihat nilai Tolerance dan nilai VIF (Variance Inflation Factor). Penentuan fungsi kanonik bisa dilakukan dengan menggunakan matriks covarian atau matriks korelasi. Hal yang membedakan keduanya adalah data yang digunakan dalam analisis.

Matriks korelasi digunakan jika data sudah dibakukan (memiliki satuan yang sama), sedangkan matriks covarian menggunakan data sebenarnya (data tidak dibakukan dan memiliki satuan yang sama). Proses penentuan fungsi kanonik dari kedua jenis matriks tersebut sama.

\section{HASIL DAN PEMBAHASAN}

\section{Uji Asumsi pada Analisis Korelasi Kanonik}

Pada analisis korelasi kanonik terdapat beberapa asumsi yang harus dipenuhi terlebih dahulu sebelum melakukan analisis diantaranya asumsi normalitas, asumsi linearitas dan asumsi multikolinearitas.

\section{Hasil Uji Normalitas}

BerdasarkanTabel Uji Normalitas dapat dilihat bahwa terdapat 14 variabel yang memenuhi asumsi normalitas ( $\mathrm{p}>$ $0,05)$ yaitu variabel dan 1 variabel yang tidak memenuhi asumsi normalitas ( $\mathrm{p}>$ 0,05) yakni variabel Pekerjaan dan akan dikeluarkan dari analisis kanonikal

Tabel 1. Hasil Uji Normalitas

\begin{tabular}{|l|c|c|c|}
\hline \multicolumn{1}{|c|}{ Variabel } & $\mathbf{N}$ & $\begin{array}{c}\text { Kolmogorov- } \\
\text { Smirnov Z }\end{array}$ & $\mathbf{P}$ \\
\hline Usia & 96 & 0.789 & 0.234 \\
\hline Pendapatan & 96 & 0.676 & 0.819 \\
\hline Pekerjaan & 96 & 2.341 & 0.001 \\
\hline KL1 & 96 & 0.689 & 0.423 \\
\hline KL2 & 96 & 0.235 & 0.533 \\
\hline KL3 & 96 & 0.234 & 0.235 \\
\hline KL4 & 96 & 0.324 & 0.643 \\
\hline KP1 & 96 & 0.325 & 0.342 \\
\hline KP2 & 96 & 0.643 & 0.533 \\
\hline KP3 & 96 & 0.242 & 0.636 \\
\hline KP4 & 96 & 0.214 & 0.351 \\
\hline PK1 & 96 & 0.634 & 0.346 \\
\hline PK2 & 96 & 0.754 & 0.352 \\
\hline PK3 & 96 & 0.865 & 0.326 \\
\hline PK4 & 96 & 0.453 & 0.743 \\
\hline
\end{tabular}

Data diolah SPSS 2021

\section{Asumsi Linearitas}


Linearitas dapat dilihat melalui uji ANOVA, apabila nilai $\mathrm{p}<\alpha$ maka model berbentuk linear.

Tabel 2. Hasil Uji Asumsi Linearitas

\begin{tabular}{|l|l|l|l|}
\hline \multicolumn{1}{|c}{ dengan ANOVA } \\
\hline Variabel & \multicolumn{1}{c|}{ F } & P & Ket \\
\hline Usia*KP & 6.591 & 0.016 & Linear \\
\hline Pendapatan*KP & 5.773 & 0.023 & Linear \\
\hline Pendapatan*PK & 4.758 & 0.002 & Linear \\
\hline KL*KP & 9,447 & 0.004 & Linear \\
\hline KL*PK & 17,100 & 0.001 & Linear \\
\hline & 8,948 & 0.005 & Linear \\
\hline
\end{tabular}

\section{Analisis Korelasi Kanonik}

Pembentukan fungsi kanonikal digunakan sebagai penetapan fungsi yang dapat dianalisis lebih lanjut untuk digunakan dalam interpretasi terhadap hasil Canonical Variates. Di dalam persamaan (model) penelitian ini, terdapat 2 variabel dependen dan tiga variabel independen, maka akan terbentuk dua fungsi Kanonikal. Berikut ini ditampilkan output hasil perhitungan:

EFFECT .. WITHIN CELLS Regression Multivariate Tests of Significance $(\mathrm{S}=2$, $\mathrm{M}=0, \mathrm{~N}=441 / 2$ )

Test Name

Value

Approx. F

Hypoth. DF

Error DF

Sig. of $\mathrm{F}$

\begin{tabular}{lccc} 
Pillais & & .05004 & .78699 \\
6.00 & 184.00 & .581 & \\
Hotellings & & .05142 & .77125 \\
6.00 & 180.00 & .593 & \\
Wilks & \multicolumn{4}{c}{.95054} & .77913 \\
6.00 & 182.00 & .587 & \\
Roys & \multicolumn{2}{c}{.03153} &
\end{tabular}

Note.. F statistic for WILKS' Lambda is exact.

- - - - - Eigenvalues and Canonical

Correlations

Root No. Eigenvalue

Cum. Pct. Canon Cor. Sq. Cor $\begin{array}{lll}1 & .03256 & 63.31993\end{array}$

$\begin{array}{lll}63.31993 & .17757 \quad .03153\end{array}$

$\begin{array}{lll}2 & .01886 & 36.68007\end{array}$

$\begin{array}{lll}100.00000 & .13605 \quad .01851\end{array}$

Dimension Reduction Analysis

Roots Wilks L. F Hypoth. DF Error DF Sig. of F

$\begin{array}{lccc}1 \text { TO } 2 & & .95054 & .77913 \\ 6.00 & 182.00 & .587 & \\ 2 \text { TO } 2 & & .98149 & .86755 \\ 2.00 & 92.00 & .423 & \end{array}$

EFFECT .. WITHIN CELLS Regression (Cont.)

Univariate F-tests with $(2,93) \mathrm{D}$. F.

Variable Sq. Mul. R Adj. R-sq. Hypoth. MS Error MS F Sig. of $\mathrm{F}$

$\begin{array}{lll}\text { Usia } & .02355 & .00255\end{array}$

$\begin{array}{lll}36.82416 & 32.83879 & 1.12136\end{array}$

.330

$\begin{array}{lll}\text { Pendapat } & 01942 \quad .00000\end{array}$

$350329753785.1 \quad 380370014525.1$

$.92102 \quad .402$

KL $\quad .00595 \quad 00000$

$\begin{array}{lll}1.29650 & 4.65626 & .27844\end{array}$

.758

Raw canonical coefficients for DEPENDENT variables

Function No.

$\begin{array}{lll}\text { Variable } & 1 & 2\end{array}$

$\begin{array}{lcc}\text { Usia } & .13884 & -.10358 \\ \text { Pendapat } & .00000 & .00000\end{array}$ 
KL

.09841

.20085

Standardized canonical coefficients for DEPENDENT variables

Function No.

\begin{tabular}{lcc} 
Variable & \multicolumn{1}{c}{1} & 2 \\
Usia & .79666 & -.59431 \\
Pendapat & -.71857 & -.53206 \\
KL & .21074 & .43009 \\
& & \\
\hline
\end{tabular}

- - - - - Correlations between DEPENDENT and canonical variables Function No.

\begin{tabular}{lcc} 
Variable & \multicolumn{1}{c}{1} & 2 \\
Usia & .66329 & -.72297 \\
Pendapat & -.60810 & -.64758 \\
KL & .16428 & .52497 \\
& & \\
\hline & & \\
\hline
\end{tabular}

Variance in dependent variables explained by canonical variables

CAN. VAR. Pct Var DEP Cum Pct DEP Pct Var COV Cum Pct COV

\begin{tabular}{ccc}
1 & 27.89100 & 27.89100 \\
.87942 & .87942 & \\
2 & 40.58821 & 68.47922 \\
.75132 & 1.63074 & \\
\multicolumn{4}{c}{} \\
\hdashline \\
Raw canonical & coefficients & for \\
COVARIATES & & \\
\multicolumn{3}{c}{ Function No. }
\end{tabular}

$\begin{array}{lrrr}\text { COVARIATE } & 1 & 2 \\ & & & \\ \text { KP } & .41786 & .18654 \\ \text { PK } & -.21227 & .45148\end{array}$

Standardized canonical coefficients for COVARIATES CAN. VAR.

$\begin{array}{lll}\text { COVARIATE } & 1 & 2\end{array}$

$\begin{array}{lll}\text { KP } & .91332 & .40773 \\ \text { PK } & -.42556 & .90514\end{array}$

Correlations between COVARIATES and canonical variables

CAN. VAR.

$\begin{array}{lll}\text { Covariate } & 1 & 2\end{array}$

$\begin{array}{lll}\text { KP } & .90497 & .42548 \\ \text { PK } & -.40765 & .91314\end{array}$

Variance in covariates explained by canonical variables

CAN. VAR. Pct Var DEP Cum Pct DEP Pct Var COV Cum Pct COV

$\begin{array}{ccc}1 & 1.55310 & 1.55310 \\ 49.25703 & 49.25703 & \\ 2 & .93929 & 2.49239\end{array}$

$50.74297 \quad 100.00000$

Regression analysis for WITHIN CELLS error term

--- Individual Univariate .9500 confidence intervals

Dependent variable .. Usia

COVARIATE

B

Beta

Std. Err. t-Value Sig. of $t$ Lower 95\% CL- Upper 
SULTANIST: Jurnal Manajemen dan Keuangan, Vol 9 (2), Desember 2021

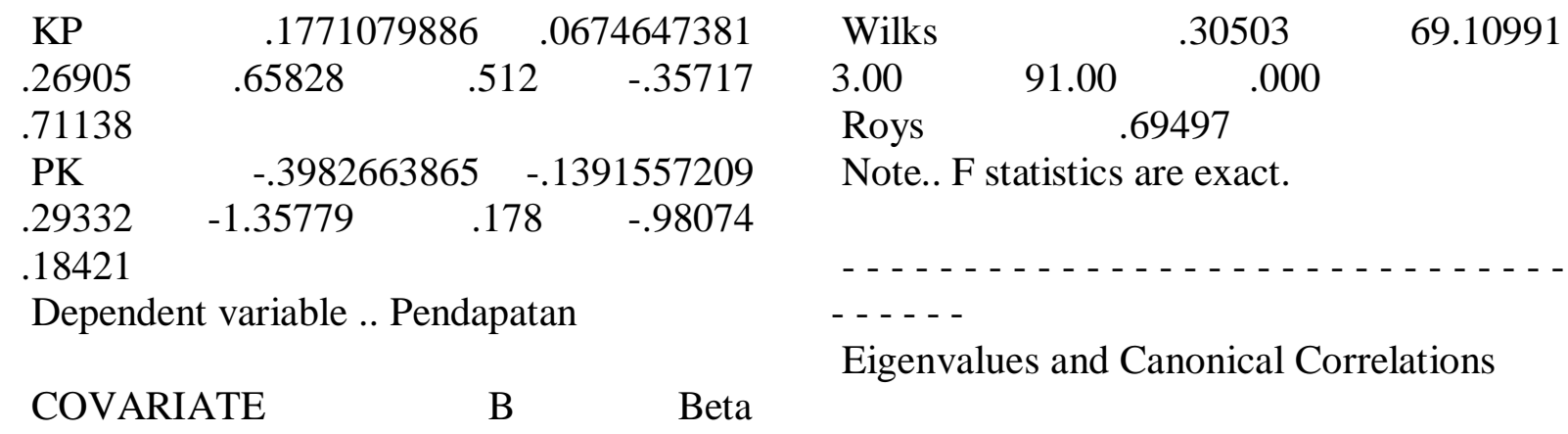

Std. Err. t-Value Sig. of $t$ Lower - Root No. Eigenvalue Pct. 95\% CL- Upper

Cum. Pct. Canon Cor.

\begin{tabular}{|c|c|c|c|c|}
\hline KP & -37932.8258468 & -.1345425939 & 1 & 100.00000 \\
\hline 28955.99758 & $\begin{array}{ll}8 & -1.31002\end{array}$ & $.193-$ & 100.00000 & .83365 \\
\hline 95433.69838 & 19568.04669 & & & \\
\hline $\mathrm{PK}$ & -10387.8973302 & -.0337956631 & & \\
\hline 31568.19915 & $5 \quad-.32906$ & $.743-$ &.---- & \\
\hline $73076.0844 \mathrm{C}$ & 52300.28983 & & EFFECT .. & NSTANT (Cont.) \\
\hline Dependent & variable .. KL & & Univariate & sts with $(1,93)$ D. F. \\
\hline
\end{tabular}

COVARIATE B Beta Variable Hypoth. SS Error SS

Std. Err. t-Value Sig. of t Lower - Hypoth. MS $\quad$ Error MS 95\% CL- Upper Sig. of F

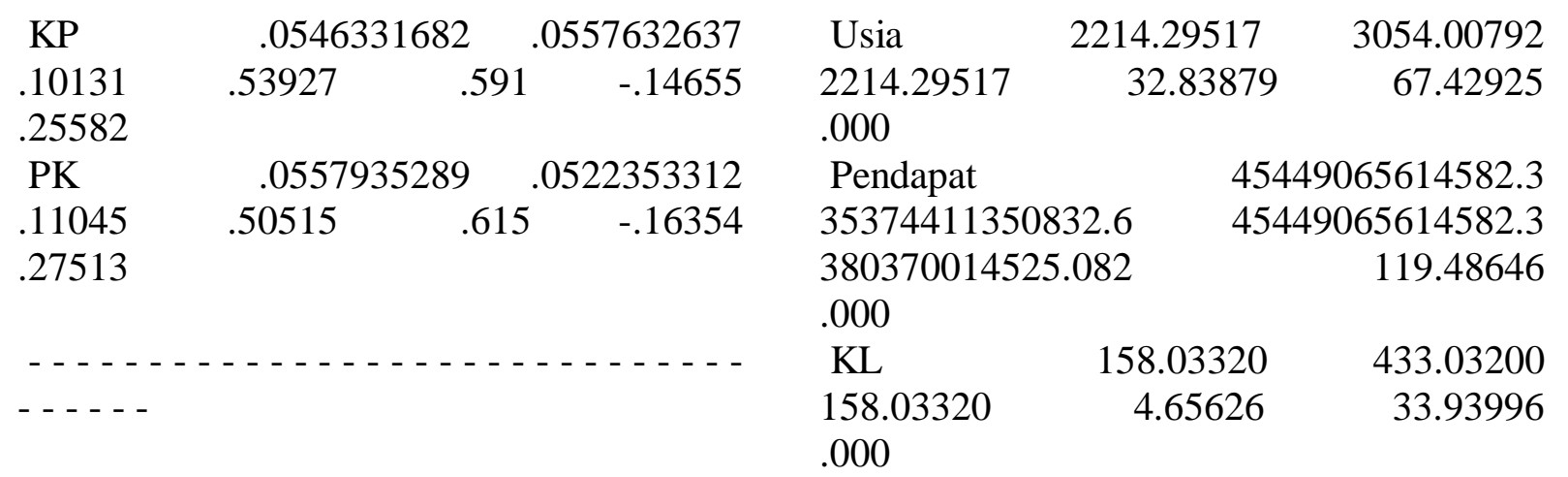

Analysis of Variance-- Design 1

\section{EFFECT .. CONSTANT}

Multivariate Tests of Significance $(\mathrm{S}=1$, $M=1 / 2, N=441 / 2$ )

$\begin{array}{lccc}\begin{array}{l}\text { Test Name } \\ \text { Hypoth. DF }\end{array} & \begin{array}{c}\text { Value } \\ \text { Error DF }\end{array} & \begin{array}{c}\text { Exact F } \\ \text { Sig. of F }\end{array} \\ \text { Pillais } & & .69497 & 69.10991 \\ 3.00 & 91.00 & .000 & \\ \text { Hotellings } & 2.27835 & 69.10991 \\ 3.00 & 91.00 & .000 & \end{array}$

\section{EFFECT .. CONSTANT (Cont.)}

Raw discriminant function coefficients Function No.

Variable

1 


\section{- . . - . Standardized discriminant function coefficients \\ Function No.}

\begin{tabular}{lc} 
Variable & \multicolumn{1}{c}{1} \\
Usia & -.50474 \\
Pendapat & -.69280 \\
KL & -.48726 \\
& \\
\hline
\end{tabular}

Estimates of effects for canonical variables Canonical Variable

Parameter $\quad 1$

$1 \quad-11.88561$

Correlations between DEPENDENT and canonical variables

Canonical Variable

Variable

Usia $\quad .56412$

Pendapat $\quad .75094$

KL $\quad-.40022$

\section{Interpretasi Fungsi Kanonik}

Interpretasi fungsi kanonik dilakukan dengan interpretasi koefisien bobot kanonik (canonical weights) dan muatan kanonik (canonical loadings). Berdasarkan hasil outpu analisis kanonik dapat dilihat bahwa pada kelompok variabel dependen, variabel Kepuasan Pelanggan memiliki kontribusi lebih besar dibandingkan dengan variabel Pembelian Kembali. Pada kelompok variabel independen, variabel Kualitas Layanan memiliki kontribusi yang lebih besar jika dibandingkan dengan variabel Usia dan Penghasilan

\section{Muatan Kanonik (Cannonical Loadings)}

Muatan kanonik menjelaskan korelasi antara fungsi kanonik dengan peubah asal. Semakin besar nilai loading mencerminkan semakin dekat hubungan antara fungsi kanonik yang bersangkutan dengan peubah asal. Berdasarkan hasil output analisis kanonik dilihat bahwa pada kelompok variabel dependen muatan kanonik kedua variabel hampir sama nialinya yakni muatan kanonik variabel Kepuasan Pelangga dan muatan kanonik variabel Pembelian Kembali. Sedangkan pada kelompok variabel independen muatan kanonik variabel Kualitas Layananlebih tinggi dibandingkan muatan kanonik variabel Pendapatan dan Umur dan umur $(-0,524)$.

\section{PEMBAHASAN}

\section{Hubungan Karakteristik Pelanggan dengan Kepuasan Pasien}

Hasil penelitian pada analisis bivariat menunjukkan bahwa usia dan tingkat pendapatan memiliki hubungan signifikan dengan kepuasan konsumen. Usia dan pendapatan sebuah jika dihubungkan secara langsung mungkin tidak relatif sulit dijelasakan, akan tetapi tanpa memandang usia, seseorang akan selalu menginginkan kepuasan dari barang dan jasa yang dia gunakan. Perbedaan usia juga mempengaruhi selera dan pengambilan keputusan tetapi tidak berpengaruh pada ekspektasi dan harapannya dalam mengkonsumsi sesuatu barang.

Hal ini jika dikaitkan dengan penelitian Berdasarkan penelitian Phau dan Baird (2008) menyatakan adanya hubungan positif antara pendapatan serta perilaku keluhan. Dimana Konsumen yang memiliki pendapatan lebih tinggi akan cenderung lebih mudah mengajukan keluhan dibandingkan dengan daripada yang lebih muda. Demikian juga tingkat pendapatan, dimana seseorang dengan pendapatan lebih dari $\$ 40.000$ lebih cenderung untuk melakukan keluhan dibandingkan dengan 
seseorang yang mempunyai tingkat pendapatan yang lebih rendah. Hal ini didukung oleh penelitian Ngai et al. (2006) yang menyatakan hubungan signifikan antara umur dan perilaku keluhan. Hal ini mungkin sedikit menerangkan bagaimana usia dan tingkat pendapatan memiliki hubungan dengan kepuasan konsumen.

\section{Hubungan Karakteristik Pelanggan dengan Pembelian Kembali}

Hasil penelitian pada analisis bivariat menunjukkan bahwa usia dan tingkat pendapatan tidak memiliki hubungan signifikan dengan keputusan melakukan pembelian kembali. Hal ini menunjukkan bahwa pembelian kembali tidak ditentukan oleh karakteristik pelanggan akan tetapi ada faktor lain yang mempengaruhi keputusan pembelian kembali, dalam penelitian ini seperti kepuasan pelanggan.

\section{Hubungan antara Kualitasa Layanan dan Kepuasan Pelanggan}

Hasil penelitian menunjukkan kualitas layanan memiliki hubungan cukup kuat dengan kepuasan pelanggan dengan nilai koefisien korelasi sebesar 0,667 dan bersifat positif, artinya jika kualitas pelayanan semakin meningkat maka kepuasan pelanggan akan semakin meningkat pula. Hasil penelitian tentang kualitas pelayanan dengan kepuasan pelanggan oleh Jahanshani, Hajizadeh et al., (2014) mengatakan bahwa layanan pelanggan dan kualitas produk berpengaruh pada kepuasan pelanggan dan juga ada hubungan positif antara customer service dan kualitas produk dengan kepuasan dan loyalitas pelanggan serta menunjukkan bahwa positif tinggi korelasi antara konstruksi layanan pelanggan dan kualitas produk dengan kepuasan pelanggan dan loyalitas.

Hal ini sejalan dengan riset dari Hasyim (2015) yang mencatat terdapat hubungan antara kualitas pelayanan dengan kepuasan masyarakat, dimana dibuktikan dengan uji korelasi Rank Spearman (rs) sebesar rs hitung $(0,645)>(0,198)$ rs tabel artinya hipotesis nol (H0) ditolak dan hipotesis alternatif (H1) diterima, dengan tes dua sisi artinya terdapat hubungan yang signifikan. Hussain dan Hussain (2015) juga menemukan dalam risetnya dengan menggunakan pendekatan kuantitatif, data dari 253 kuesioner dianalisis, kemudian dengan menggunakan pemodelan persamaan struktural, analisis data menunjukkan bahwa kualitas layanan, perceived value, dan brand image berpengaruh positif signifikan terhadap kepuasan pelanggan, yang pada gilirannya dapat menyebabkan meningkatnya loyalitas mereka

\section{Hubungan Kualitas Layanan dengan Pembelian Kembali}

Kualitas pelayanan memiliki hubungan yang signifikan dengan pembelian kembali. Hal ini menunjukkan kualitas pelayanan dapat mempengaruhi pembelian kembali maka suatu kualitas pelayanan yang dikatakan baik akan memuaskan pelanggan terlebih dahulu. Kepuasan pelanggan merupakan ukuran kinerja sebuah organisasi dibandingkan serangkaian keperluan pelanggan . Kualitas pelayanan ini menjadi penting karena akan berdampak langsung pada citra perusahaan. Kualitas pelayanan yang baik akan menjadi sebuah keuntungan bagi perusahaan. Maka dari itu, sangat penting untuk mempertimbangkan aspek kepuasan pelanggan terkait kualitas pelayanan yang diberikan.

\section{SIMPULAN DAN SARAN}

\section{Kesimpulan}

Terdapat hubungan secara bersamasama antara karakteristik konsumen yakni usia dan tingkat pendapatan dan kualitas pelayanan dengan kepuasan konsumen dan keputusan pembelian kembali. Sedangkan karakteristik berdasarkan pekerjaan tidak dianalisis karena tidak memenuhi asumsi normalitas. Tingkat korelasi kanonik antara 
kelompok variabel dependen dan independen pada fungsi 1 adalah sebesar 0,694 . Dengan batas 0,5 , dapat disimpulkan bahwa tingkat hubungan antar variabel secara keseluruhan cukup kuat. Variabel independen yang mempunyai hubungan paling kuat yakni yang memiliki dengan nilai muatan kanonik terbesar dengan kepuasan konsumen dan keputusan pembelian kembali adalah variabel kualitas pelayanan. Variabel yang memiliki kontribusi terbesar dalam kelompok variabel dependen adalah variabel kepuaasan pelanggan dengan bobot kanonik terbesar. Sedangkan variabel yang memiliki kontribusi paling besar dalam kelompok variabel independen adalah variabel kualitas pelayanan dengan bobot kanonik terbesar.

Kepuasan pelanggan merupakan faktor terpenting yang harus diperhatikan perusahaan karena pelanggan merupakan alasan mengapa suatu perusahaan eksis. Dan tanpa pelanggan perusahaan tidak dapat mempertahankan kelangsungan hidupnya. Pelanggan merupakan elemen dasar dari setiap bisnis. Pelanggan merupakan faktor penentu bagi eksistensi suatu perusahaan. Dari pelangganlah sumber pendapatan perusahaan berasal. Semakin banyak pelanggan semakin banyak pula peluang pendapatan didapatkan. Semakin banyak frekuensi pembelian, semakin banyak pula peluang peningkatan pendapatan. Dari hasil penelitian ini setiap pelaku bisnis semakin menyadari akan pentingnya memuaskan pelanggan. Apabila manfaat yang diberikan melebihi harapan konsumen maka konsumen akan merasa puas, sebaliknya apabila kurang dari harapan maka akan kecewa. Dengan tingkat kepuasan yang tinggi selanjutnya akan meningkatkan loyalitas konsumen. Konsumen lama bisa dipertahankan dan semakin sering melakukan pembelian kembali.

\section{DAFTAR PUSTAKA}

Abu Bakar. 2015. Hubungan Antara Kualitas Pelayanan Dengan Kepuasan Masyarakat DiKelurahan Karang Asam Ulu Kecamatan Sungai Kunjang Kota Samarinda. eJournal Ilmu Pemerintahan, 3 (2), 2015: 1284 1297 ISSN0000-0000, ejournal.ip.fisip.unmul.ac.id

Hair, J.F., R.E. Anderson. 2010. Multivariate Data Analysis. Seventh Edition. Pearson Prentice Hall International Inc, New

Hotelling, H. 1936. Relations Between Two Sets of Variates. Biometrika. 28(1). 312-377.

Jersey.Hussain, R., Al Nasser, A., \& Hussain, Y. K. (2015). Service quality and customer satisfaction of a UAEbased airline: An empirical investigation. Journal of Air Transport Management, 42, 167-175.

Ngai, Eric W.T; Vincent C.S. Heung; Y.H. Wong and Fanny K.Y. Chan. 2006. Consumer Complaint behavior of Asians and Non-Asians about Hotel Services. European Journal of Marketing, Vol. 41, No. 11/12, pp.1375-1391.

Kasmir. 2005. Etika Customer Service. Raja Grafinfo Persada. Jakarta

Kotler, Philip. 2005. Manajemen Pemasaran. Jilid I, Jakarta: Indeks.

Kotler,Philip dan Kevin Lane Keller. 2009. Manajemen Pemasaran. Edisi 13. Erlangga. Jakarta

Phau, Ian and Michael Baird. 2008. Complainers Versus Non-Complainers Retaliatory Responses Towards Service Dissatisfaction. Marketing Intelligence and Planning, Vol. 26, No. 6, pp. 587-604.

Rumondang, A., Sudirman, A., Sitorus, S., Kusuma, A. H. P., Manuhutu, M., Sudarso, A., Simarmata, J., Hasdiana, D., Tasnim, \& Arif, N. F. (2020). Pemasaran Digital dan Perilaku 
Konsumen (Cetakan 1). Yayasan Kita Menulis.

Sudirman, A., Efendi, E., \& Harini, S. (2020). Kontribusi harga dan kepercayaan konsumen untuk membentuk kepuasan pengguna transportasi berbasis aplikasi. Journal of Business and Banking, 9(2), 323335.

Sudirman, A., Sherly, Butarbutar, M., Nababan, S. T., \& Puspitasari, D. (2020). Loyalitas Pelanggan Pengguna Gojek Ditinjau Dari Aspek Kualitas Pelayanan dan Kepuasan Konsumen.
Procuration: Jurnal Ilmiah

Manajemen, 8(1), 63-73.

Sugiyono. 2010. Statistika Untuk Penelitian. CV Alfabeta. Bandung

----------. 2016. Metode Penelitian (Pendidikan Kuantitatif, Kualitatif dan $\mathrm{R} \& \mathrm{D}$.

Tjiptono, F., \& Sunyoto, D. (2012). Dasar Dasar Manajemen Pemasaran. Jakarta: Gramedia Pustaka.

Tjiptono, Fandy. 2007. Strategi Pemasaran. Edisi Kedua. Yogyakarta : Andi Ofset. 